\title{
PENGARUH PENERAPAN PRINSIP GOOD GOVERNANCE DAN INTENSITAS SOSIALISASI TERHADAP PENERIMAAN WAKAF TUNAI
}

\author{
THE EFFECT OF APPLICATION OF GOOD GOVERNANCE PRINCIPLES AND INTENSITY \\ OF SOCIALIZATION ON ADMISSION OF CASH WAKAF
}

\author{
Fahma As'har Hariyanto \\ Universitas Islam Malang \\ fahma.ashar@gmail.com
}

\begin{abstract}
Cash waqf is the implementation of the development of waqf, which is carried out by collecting cash waqf certificates issued by Islamic financial institutions. Optimizing collection and management of waqf requires good governance, therefore Good Governance is believed to be a benchmark for the good or not of an organization's performance. The importance of the intensity of socialization of cash waqf is also an important point in removing the gap between potential and existing realization. The purpose of this study is to find out whether there are influences on the application of the principles of good governance and the intensity of cash waqf acceptance and how much influence the principle applies good governance and the intensity of socialization on the level of acceptance of cash waqf. The methodology used is a quantitative method with a survey approach. The results of the research show that the application of the principles of good governance has a significant effect on the level of acceptance of cash waqf. Research that was only conducted in 10 waqf management institutions made the diversity of opinions from other waqf management institutions not yet concluded properly.
\end{abstract}

Keywords: Good governance, Intensity of socialization, and cash waqf.

Abstrak. Wakaf tunai merupakan implementasi dari perkembangan wakaf, yang dilakukan dengan cara menghimpun sertifikat wakaf tunai yang dikeluarkan oleh lembaga keuangan syariah. Pengoptimalan penghimpunan dan pengelolaan wakaf membutuhkan adanya tata kelola yang baik, karenanya Good Governance dipercaya sebagai tolak ukur baik tidaknya kinerja suatu organisasi. Tujuan dari penelitian ini adalah untuk mengetahui apakah ada pengaruh penerapan prinsip good governance terhadap penerimaan wakaf tunai dan seberapa besar pengaruh penerapan prinsip good governance terhadap penerimaan wakaf tunai. Metodologi yang digunakan adalah metode kuantitatif dengan pendekatan survei. Hasil penelitiaan menunjukan bahwa penerapan prinsip good governance berpengaruh signifikan terhadap tingkat penerimaan wakaf tunai. Penelitian yang hanya dilakukan di 10 lembaga pengelola wakaf menjadikan keberagaman pendapat dari lembaga pengelola wakaf lain belum dapat disimpulkan dengan baik.

Kata kunci: Good Governance, nazhir, dan wakaf tunai. 


\section{A. Pendahuluan}

Wakaf tunai merupakan salah satu implementasi dalam perkembangan wakaf. Perkembangan wakaf tunai di Indonesia memiliki potensi yang sangat besar, bahkan tercatat sebesar Rp 180 triliun. Sayangnya, potensi yang besar tidak dapat menjamin bahwa wakaf akan terealisasi dengan baik, karena dari lembaga pengelola wakaf masih banyak yang tidak mampu untuk mengumpulkan potensi wakaf tersebut. Masalah yang menjadi penyebab utama lembaga pengelola wakaf belum optimal menghimpun potensi wakaf adalah masih sedikit wakaf yang dikelola secara profesional dan produktif (bwi.or.id, 2013). Menurut data Kementerian Agama RI Tahun 2010, hampir 95\% aset wakaf belum dimanfaatkan secara optimal sehingga peran wakaf belum maksimal. Good Governance yang masih lemah juga menyebabkan kurang adanya transparansi dan akuntabilitas nazhir kepada para wakif maupun calon wakif sehingga kepercayaan masyarakat berkurang pada nazhir atau lembaga pengelola wakaf.

Optimalisasi penghimpunan dan pengelolaan wakaf membutuhkan adanya tata kelola yang baik (Budiman, 2011). Menurut The Indonesian Institute for Corporate Governance (IICG) "Good Corporate Governance merupakan serangkaian mekanisme yang mengarahkan dan mengendalikan suatu perusahaan agar operasional perusahaan berjalan sesuai dengan harapan para pemangku kepentingan (stakeholders)". Good Governance dipercaya sebagai tolak ukur baik tidaknya kinerja suatu organisasi. Terdapat lima prinsip dalam good governance yang dikemukakan oleh Komite Nasional Kebijakan Governance (KNKG) yaitu transaparansi, akuntabilitas, responsibilitas, independensi dan fairness.

Potensi wakaf uang yang begitu besar seharusnya bila dikelola dengan baik akan menghasilkan penghimpunan dana wakaf uang yang besar tapi kenyataannya terjadi gap yang sangat lebar antara realisasi dana wakaf yang dihimpun dengan potensi wakaf uang yang ada. Rendahnya pemanfaatan wakaf ini identik dengan rendahnya pengetahuan wakif. Masih rendahnya tingkat pemahaman wakif mengenai wakaf uang dan pemahaman Undang-undang No.41 Tahun 2004 tentang wakaf merupakan suatu realita yang tidak dapat terbantahkan. Masyarakat pada umumnya masih belum mengetahui betul apa itu wakaf dan kegunaan wakaf itu sendiri. Pengamat ekonomi syariah, Wibisono (2018) sepakat bahwa wakaf tunai butuh sosialisasi lebih, selain untuk menjangkau lebih banyak orang namun juga untuk menngkatkan pemahaman masyarakat dan transparansi pengelolaannya. Seharusnya ini menjadi perhatian penting bagi pemerintah khususnya lembaga pengelola wakaf untuk terus melakukan sosialisasi agar wakaf tunai terus produktif membangun Indonesia yang lebih baik.

Berdasarkan uraian dan paparan dari latar belakang diatas, serta untuk memperjelas objek penelitian, maka peneliti membatasi dan merumuskan rumusan masalah "Bagaimana pengaruh penerapan prinsip good governance dan intensitas sosialisasi terhadap tingkat penerimaan wakaf tunai?".

Adapun tujuan yang ingin dicapai pada penelitian ini adalah untuk mengetahui pengaruh penerapan prinsip good governance dan intensitas sosialisasi terhadap tingkat penerimaan wakaf. 
Hasil dari penelitian ini diharapkan dapat berguna dan bermanfaat bagi penulis dan pihak lain yang bersangkutan. Bagi penulis diharapkan penelitian ini dapat menambah wawasan serta pengetahuan mengenai lembaga pengelola wakaf, khususnya dilihat dari faktor yang mempengaruhi penerimaan wakaf tunai. Bagi lembaga pengelola wakaf, diharapkan penelitian ini menjadi masukan bagi lembaga pengelola wakaf di Indonesia untuk dapat meningkatkan penerimaan wakaf tunai. Selanjutnya, bagi peneliti lain diharapkan penelitian ini dapat memberikan tambahan pengetahuan dan pemahaman teoritis serta penerapannya terhadap kondisi nyata di lapangan terutama mengenai masalah penerimaan wakaf tunai.

\section{B. Landasan Teori \\ Good Governance}

Berdasarkan PP No. 101 tahun 2000 pengertian Good Governance adalah "pemerintahan yang mengembangkan dan menetapkan prinsip-prinsip profesionalitas, akuntabilitas, transparansi, pelayanan prima, demokrasi, efisiensi, efektivitas, supremasi hukum dan dapat diterima oleh seluruh masyarakat". Cita Good Governance kini sudah menjadi bagian sangat serius dalam wacana pengembangan paradigma birokrasi dan pembangunan kedepan. Karena peranan implementasi dari prinsip Good Governance adalah untuk memberikan mekanisme dan pedoman dalam memberikan keseimbangan bagi para stakeholders dalam memenuhi kepentingannya masing-masing. Terdapat lima prinsip Good Governance yang dikeluarkan Komite Nasional Kebijakan Governance (KNKG) yaitu transparansi, akuntabilitas, responsibilitas, independensi dan keadilan.

\section{Intensitas Sosialisasi}

Menurut Kamus Besar Bahasa Indonesia, sosialisasi adalah usaha untuk mengubah milik perseorangan menjadi milik umum atau upaya memasyarakatkan sesuatu sehingga menjadi dikenal, dipahami, dihayati oleh masyarakat. Sosialisasi memiliki andil yang cukup besar dalam meningkatkan penerimaan wakaf tunai. Berbagai media dan upaya pemerintah juga lembaga pengelola wakaf diharapkan mampu menggugah kesadaran masyarakat untuk pentingnya pajak bagi negara. Soekanto (2013) mengartikan sosialisasi sebagai proses sosial tempat seorang individu mendapatkan pembentukan sikap untuk berperilaku yang sesuai dengan perilaku orangorang di sekitarnya.

Intensitas sosialisasi ke masyarakat sangat penting dalam rangka peningkatan penerimaan wakaf tunai. Wakaf hanya dipahami sebagai ibadah mahdhah saja padahal wakaf juga dipahami operasionalnya dan pengembangan dari wakaf itu sendiri digunakan untuk syiar serta kemaslahatan umat. Paradigma tersebut yang menyebabkan masyarakat masih berfikir konvensional belum mengarah ke arah yang produktif. Hal ini menyebabkan sebuah strategi tersendiri untuk dapat mempopulerkan pemahaman fiqh tentang wakaf uang terhadap masyarakat dengan pemahaman yang sudah ada.

\section{Penerimaan Wakaf Tunai}

Wakaf tunai merupakan hal baru di Indonesia yang merupakan produk dari Undang Undang No.41 Tahun 2004. Wakaf tunai menurut UU No.41 tahun 2004 pasal 28 sampai pasal 31 yaitu wakaf benda bergerak berupa uang yang diterbitkan dalam bentuk sertifikat wakaf uang oleh lembaga keuangan syariah sebagai bukti penyerahan harta benda wakaf. 
Pasal 28 Undang-undang Nomor 41 Tahun 2004 tentang Wakaf ditentukan bahwa wakif dalam mewakafkan benda bergerak berupa uang melalui lembaga perbankan syariah yang ditunjuk oleh Menteri. Dana wakaf yang diperoleh dari para wakif akan dikelola oleh nazhir (pengelola wakaf) yang dalam hal ini bertindak sebagai manajemen investasi. Kemudian dana wakaf tersebut dikelola dan diinvestasikan sebagian pada instrumen keuangan syariah, sebagian lagi diinvestasikan langsung ke berbagai badan usaha yang bergerak sesuai syariah, dapat juga portofolio investasi lainnya adalah menyalurkan dana melalui kredit mikro ke sektor-sektor yang mampu mengurangi pengangguran dan menciptakan calon-calon wirausaha baru.

\section{Penelitian Terdahulu}

Hasbar (2016) juga melakukan penelitian dengan judul "Analisis Implementasi Good Corporate Governance dan Penetapan PSAK 109 Tentang Akuntansi Zakat pada Lembaga Amil Zakat Dompet Dhuafa Cabang Sulawesi Selatan". Penelitian tersebut menunjukan bahwa Prinsip-prinsip Good Corporate Governance $(G C G)$ telah di implementasikan, walaupun secara legalitas kebijakan belum secara formil diterapkan. Pedoman Standar Akuntansi Keuangan (PSAK) 109 tentang Akunatnsi Zakat juga telah diterapkan pada Lembaga Amil Zakat Dompet Dhuafa Cabang Sulawesi Selatan.

Penelitian yang dilakukan oleh Yuliafitri (2017) tentang "Pengaruh Penetapan PrinsipPrinsip Good Governance dan Promosi Terhadap Penerimaan Wakaf Tunai (Pada Lembaga

Pengelola Wakaf di Indonesia" menunjukkan bahwa penerapan prinsip-prinsip good governance dan promosi berpengaruh positif secara signifikan terhadap penerimaan wakaf tunai di lembaga pengelola wakaf.

Penelitian yang dilakukan oleh Triwibowo (2017) tentang "Penerapan Prinsip-Prinsip Good Corporate Governance dalam Pengelolaan Wakaf Tunai pada Badan Wakaf Uang Tunai MUI Yogyakarta" membuktikan bahwa penerapan prinsip-prinsip GCG belum diterapkan secara keseluruhan. Kekurangan menonjol terletak pada prinsip transparansi dan akuntabilitas.

\section{Metodologi Penelitian}

Jenis penelitian yang digunakan dalam penelitian ini adalah metode penelitian kuantitatif dengan pendekatan survei. Metode pengambilan sampel dilakukan dengan purposive sampling.

Berdasarkan kriteria sampel yang telah ditentukan sebelumnya, penelitian ini dilakukan di 10 lembaga pengelola wakaf yang memenuhi kriteria tersebut, yaitu: Aksi Cepat Tanggap Malang, BMH Malang, Lazis NU Jawa Timur, Koperasi Masjid Sabilillah, Rumah Wakaf Gorontalo, Global Waqf Center Jakarta, BMT ANDA Semarang, Wakaf Salman ITB, BMT Permata Mojokerto, dan Yayasan Wakaf Ar-Risalah Padang.

Dalam penelitian ini, peneliti menggunakan jenis data primer. Data primer yaitu data yang diperoleh dari hasil kuesioner yang disebarkan kepada responden. Metode analisis yang digunakan adalah metode statistik dengan menggunakan analisis regresi linear berganda. Tahaptahap yang dilakukan adalah uji kualitas data meliputi uji validitas, reliabilitas, dan normalitas, uji asumsi klasik yang meliputi uji multikolinieritas dan uji heteroskedastisitas, regresi linear sederhana, uji hipotesis yang meliputi uji simultan (uji F), uji koefisien determinasi dan uji parsial (uji t).

ISSN : 1693-0164 | e-ISSN : 2581-074X 


\section{Hasil dan Pembahasan}

Kuesioner yang disebar dalam penelitian ini sebanyak 38 kuesioner kepada 10 lembaga pengelola wakaf. Dari jumlah 38 lembar kuesioner yang disebar, yang kembali adalah sebanyak 32 lembar kuesioner atau 84,2\%. Kuesioner yang tidak kembali sebanyak 6 lembar atau 15,8 \%. Kuesioner yang dapat diolah adalah sebanyak 32 lembar atau 84,2 \%, sedangkan kuesioner yang tidak dapat diolah tidak ada, karena semua kuesioner dijawab dengan lengkap.

\section{Uji Validitas}

Uji validitas digunakan untuk mengukur sah atau tidak suatu kuesioner. Hasil penelitian dapat dikatakan valid apabila nilai $r$ hitung $>r$ tabel dan jika nilai nilai $r$ hitung $<\mathrm{r}$ tabel, maka item tersebut tidak valid. Dengan menggunakan responden sebanyak 32 dan nilai signifikan 5\% maka diperoleh nilai $\mathrm{r}$ tabel sebesar 0,361 .

Berdasarkan hasil uji validitas dapat diketahui bahwa item variabel dalam penelitian ini untuk variabel Good governance berkisar antara 0,393 sampai dengan 0,724, variabel intensitas sosialisasi berkisar antara 0,474 sampai dengan 0,850, dan untuk variabel penerimaan wakaf tunai berkisar antara 0,467 sampai dengan 0,747. Seluruh item pertanyaan memiliki nilai $r$ hitung $>\mathrm{r}$ tabel sebesar 0,361 sehingga dapat disimpulkan semua item pertanyaan dalam kuesioner adalah valid.

\section{Uji Reliabilitas}

Uji reliabilitas digunakan untuk menguji konsistensi data dalam jangka waktu tertentu, yaitu untuk mengetahui sejauh mana pengukuran yang digunakan dapat dipercaya atau diandalkan. Instrumen dapat dikatakan handal apabila memiliki koefisien keandalan sebesar 0,60 atau lebih. Uji reliabilitas yang digunakan adalah dengan Cronbach Alpha.

Berdasarkan hasil penelitian dapat diketahui bahwa semua variabel tersebut memiliki nilai koefisien Cronbach Alpha lebih besar dari 0,60 dengan nilai variabel good governance sebesar 0,854, intensitas sosialisasi sebesar 0,626 dan penerimaan wakaf tunai sebesar 0,650. Sehingga dapat disimpulkan bahwa instrument pertanyaan yang digunakan dalam penelitian ini sudah reliabel atau dapat diandalkan.

\section{Uji Normalitas}

Uji normalitas bertujuan untuk menguji apakah dalam uji regresi, variabel residual memiliki distribusi normal atau tidak. Pengujian normalitas data dapat diketahui dengan menggunakan uji kolmogorov smirnov. Jika nilainya diatas 0,05 maka distribusi data dinyatakan sudah memenuhi asumsi normalitas.

Berdasarkan uji normalitas yang telah dilakukan menunjukan bahwa statistik uji Kolmogorov smirnov pada variabel Good Governance sebesar 0,740 dengan nilai signifikansi sebesar 0,644 > 0,05. Sehingga variabel Good Governance terdistribusi secara normal. Statistik uji Kolmogorov smirnov pada variabel Intensitas sosialisasi sebesar 0,999 dengan nilai signifikansi sebesar 0,271>0,05. 
Sehingga variabel intensitas sosialisasi terdistribusi secara normal. Statistik uji Kolmogorov smirnov pada variabel Penerimaan wakaf tunai sebesar 1,018 dengan nilai signifikansi sebesar 0,251 >0,05. Sehingga variabel penerimaan wakaf tunai terdistribusi secara normal.

\section{Asumsi Klasik \\ Uji Multikolinieritas}

Uji multikolinieritas bertujuan untuk menguji apakah model regresi ditemukan adanya korelasi antar variabel bebas (independen). Model regresi yang baik seharusnya tidak terjadi korelasi diantara variabel independen. Untuk mendeteksi ada atau tidaknya multikolinieritas dapat dilihat dari nilai Tolerance dan Variance Inflation Factor (VIF). Apabila nilai tolerance > 0,10 dan nilai VIF < 10, maka model regresi terbebas dari problem multikolinieritas.

Dari rangkuman tabel dapat diperoleh informasi bahwa pada variabel good governance dan intensitas sosialisasi diperoleh nilai tolerance sebesar 0,760 dan nilai VIF sebesar 1,315. Dari perhitungan masing-masing variabel bebas menunjukkan nilai tolerance $>0,10$ dan nilai VIF < 10. Sehingga dapat disimpulkan bahwa variabel bebas tersebut tidak menunjukkan gejala multikolinieritas dalam model regresi.

\section{Uji Heteroskedastisitas}

Uji heteroskedastisitas bertujuan untuk menguji apakah dalam model regresi terjadi ketidaksamaan variansi dari residual satu pengamatan ke pengamatan lain. Model regresi yang baik adalah yang tidak terjadi heteroskedastisitas. Pengujian heteroskedastisitas dalam penelitian ini menggunakan uji Glejser dengan melihat nilai signifikansi. Jika nilai signifikan >0,05 maka model regresi terbebas dari masalah heteroskedastisitas.

Berdasarkan uji Glejser, menunjukkan bahwa nilai signifikansi variabel good governance sebesar 0,548 dan variabel intensitas sosialisasi sebesar 0,984. Semua variabel menunjukkan probabilitas signifikansi lebih dari 0,05 , yang berarti tidak ada variabel independen yang signifikan secara statistic mempengaruhi variabel dependen RES2. Jadi dapat disimpulkan bahwa model regresi tidak terjadi heteroskedastisitas.

\section{Analisis Regresi Linier Berganda}

Metode analisis data merupakan metode yang digunakan untuk mengolah dan memprediksi hasil penelitian guna memperoleh suatu kesimpulan. Berdasarkan judul, latar belakang, dan perumusan masalah maka teknik analisis data yang digunakan adalah analisis regresi linier berganda yang digunakan untuk mengetahui pengaruh variabel bebas terhadap variabel terikat. Berdasarkan hasil perhitungan, diperoleh bentuk persamaan regresi linear ganda sebagai berikut :

$$
\mathrm{Y}=\underset{(\text { sig. } 0,041)}{9,492}+\underset{(\text { sig. } 0,378)}{0,139 X 1}+\underset{4,258}{0.165 X 2}
$$




\section{Uji Hipotesis}

\section{Uji Simultan (Uji F)}

Uji hipotesis ini digunakan untuk mengetahui pengaruh variabel independen Good Governance (X1) dan Intensitas Sosialisasi (X2) terhadap variabel dependen Penerimaan Wakaf Tunai (Y). Berdasarkan pada tabel nilai F sebesar 4,767 dan Sig.f sebesar 0,016, maka $\mathrm{H}_{0}$ ditolak dan $\mathrm{H}_{1}$ diterima. Jadi data dalam penelitian ini adalah signifikan, dengan demikian dapat disimpulkan bahwa good governance (X1) dan intensitas sosialisasi (X2) berpengaruh signifikan terhadap penerimaan wakaf tunai $(\mathrm{Y})$.

\section{Uji Koefisien Determinasi (Adjusted $\mathbf{R}^{\mathbf{2}}$ )}

Koefisien determinasi (Adjusted $\mathrm{R}^{2}$ ) adalah untuk mengukur seberapa jauh kemampuan model dalam menerangkan variasi variabel dependen. Nilai koefisien determinasi adalah antara nol dan satu. Nilai $\mathrm{R}^{2}$ yang kecil berarti kemampuan variabel-variabel independen dalam menjelaskan variasi variabel dependen amat terbatas. Analisis menunjukkan nilai koefisien determinasi (Adjusted $\mathrm{R}^{2}$ ) sebesar 0,196. Nilai tersebut bermakna bahwa sebesar 0,196 atau $19,6 \%$ perubahan-perubahan yang terjadi pada tingkat penerimaan wakaf tunai disebabkan oleh penerapan prinsip good governance dan intensitas sosialisasi lembaga pengelola wakaf. Sisanya 0,804 atau $80,4 \%$ menunjukkan bahwa perubahan yang terjadi pada tingkat penerimaan wakaf tunai disebabkan oleh faktor lain yang tidak dimasukkan dalam penelitian ini.

\section{Uji Parsial (Uji t)}

Pengujian model regresi secara parsial digunakan untuk mengetahui apakah variabel independen membentuk model regresi secara individu memiliki pengaruh yang signifikan terhadap variabel dependen atau tidak. Untuk menguji pengaruh tersebut, digunakan uji t, yaitu dengan membandingkan nilai signifikan $t$ dengan 0,05 . Variabel independen pembentuk model regresi dikatakan berpengaruh dignifikan jika nilai signifikan $\mathrm{t}<\alpha=0,05$.

Variabel X1 memiliki nilai statsitik uji t sebesar 2,965 dan nilai signifikan t sebesar 0,006. Nilai signifikan $\mathrm{t}$ lebih kecil dari pada $\alpha=0,05$. Pengujian ini menunjukkan bahwa $\mathrm{H}_{0}$ a ditolak dan $\mathrm{H}_{1}$ a diterima. Sehingga dapat disimpulkan bahwa variabel X (good governance) berpengaruh positif dan signifikan terhadap variabel Y (Penerimaan wakaf tunai). Dengan kata lain, apabila semakin tinggi penerapan good governance maka semakin meningkat pula tingkat penerimaan wakaf tunai. Hasil penelitian ini konsisten dengan penelitian yang dilakukan oleh Yuliafitri (2017) bahwa variabel good governance berpengaruh secara positif terhadap variabel penerimaan wakaf tunai.

Variabel X2 memiliki nilai statistik uji t sebesar 0,895 dan nilai signifikan 0,378. Dari data tersebut diperoleh nilai signifikansi lebih besar dari $\alpha=0,05$. Pengujian ini menunjukkan bahwa $\mathrm{H}_{0}$ b diterima dan $\mathrm{H}_{1}$ b ditolak. Sehingga dapat disimpulkan bahwa variabel X2 (intensitas sosialisasi) tidak berpengaruh positif dan tidak signifikan terhadap variabel Y (penerimaan wakaf tunai). Hasil penelitian ini tidak konsisten dengan penelitian yang dilakukan oleh Dahlan (2017) bahwa variabel intensitas sosialisasi merupakan faktor yang dapat mempengaruhi tingkat penerimaan wakaf tunai. 


\section{E. Simpulan dan Saran}

Adapun tujuan penelitain yang dapat diambil dari penelitian yang telah dilakukan dengan menggunakan alat uji regresi linier berganda adalah penelitian secara simultan membuktikan bahwa variabel good governance dan intensitas sosialisasi berpengaruh positif dan signifikan terhadap penerimaan wakaf tunai. Artinya semakin tinggi good governance yang diterapkan di lembaga pengelola wakaf, maka semakin tinggi pula tingkat penerimaan wakaf tunai. Namun penelitian secara parsial good governance berpengaruh secara signifikan terhadap penerimaan wakaf tunai dan intensitas sosialisasi tidak berpengaruh terhadap penerimaan wakaf tunai.

Dalam melakukan penelitian ini, peneliti menyadari bahwa penelitian ini mempunyai keterbatasan, diantaranya:

1. Penelitian ini hanya dilakukan di 10 lembaga pengelola wakaf.

2. Pengambilan sampel dalam penelitian menggunakan metode purposive sampling, yang hanya menggunakan responden sebanyak 32 .

3. Variabel Independen yang digunakan dalam penelitian ini hanya meliputi good governance dan intensitas sosialisasi yang digunakan untuk menjelaskan variabel dependen yaitu penerimaan wakaf tunai.

Saran yang dapat diberikan oleh peneliti berdasarkan hasil penelitian yang telah dilakukan adalah sebagai berikut:

1. Penelitian hanya dilakukan di 10 lembaga pengelola wakaf saja, sehingga belum bisa menyimpulkan keberagaman pendapat dari lembaga pengelola wakaf lain yang ada di Indonesia. Jadi, diharapkan untuk penelitian berikutnya dapat menggunakan responden lembaga pengelola wakaf lain yang ada di Indonesia.

2. Dalam pengambilan sampel, peneliti hanya mengambil sebanyak 32 responden. Diharapkan untuk penelitian berikutnya dapat menggunakan responden yang lebih banyak lagi.

3. Variabel Independen yang digunakan dalam penelitian ini hanya good governance dan intensitas sosialisasi yang digunakan untuk menjelaskan variabel dependen yaitu penerimaan wakaf tunai. Hal ini menyebabkan nilai uji koefisien determinasi menjadi kecil yakni sebesar 20,1\%, yang artinya 79,9\% dipengaruhi oleh variabel lain. Dengan demikian, menambahkan jumlah variabel diharapkan mampu menaikan nilai koefisien determinasi. Karena baru-baru ini telah disahkan PSAK 112 tentang wakaf, implementasi PSAK 112 dapat menjadi variabel penelitian dalam peningkatan penerimaan wakaf tunai sebagai bentuk transparansi pencatatan laporan keuangan. 


\section{F. Daftar Pustaka}

A. Mas'adi, Ghufron. 2002. Fiqh Muamalah Kontekstual. Jakarta: PT. Raja Grafindo Persada. Arikunto, S. 2010. Prosedur penelitian : Suatu Pendekatan Praktik (Edisi Revisi). Jakarta : Rineka Cipta.

Badan Wakaf Indonesia. 2013. Memproduktifkan Aset Wakaf Nasional. Situs Internet BWI. http://www.bwi.or.id. (Diakses November 2018)

Fauzia, Amelia. 2018. Wakaf Tunai Butuh Sosialisasi. Situs Internet Republika Online. http://www.republika.co.id. (Diakses November 2018)

Hasbar, Mustafa \& Nurul Gaibi. 2016. Analisis Implementasi Good Corporate Governance dan Penerapan PSAK 109 Tentang Akuntansi Zakat pada Lembaga Amil Zakat Dompet Dhuafa Cabang Sulawesi Selatan. AKMEN Jurnal Ilmiah. Vol. 13, no.1.

Indriantoro, Nur dan Bambang Supomo. 2014. Metodologi Penelitian Bisnis. Yogyakarta: BPFE.

Komite Nasional Kebijakan Governance. 2006. Pedoman Umum Good Corporate Governance Indonesia. Jakarta. KNKG.

Lutfhi, Atabik. 2018. Potensi Wakaf Tunai Capai Rp 180 Triliun. Situs Internet Republika Online. http://www.republika.co.id. (Diakses November 2018)

Mardiasmo. 2002. Akuntansi Sektor Publik. Edisi Pertama. Yogyakarta. PBFE.

Peraturan Pemerintah No. 101 Tahun 2000 tentang Pendidikan dan Pelatihan Jabatan Pegawai Negeri Sipil.

Rozzaq, Abdur. 2014. Manajemen Wakaf di Kota Malang Pasca Penetapan BWI Kota Malang. Undergraduate thesis, Universitas Islam Negeri Maulana Malik Ibrahim.

Soekanto, Soerjono. 2013. Sosiologi Suatu Pengantar. Jakarta : PT. RajaGrafindo Persada.

Sugiyono. 2016. Metodologi Penelitian Kuantitatif, Kualitatif, dan R\&D. Bandung:CV Alfabeta.

Tjokroamidjojo, Bintoro. 2014. Mewujudkan Good Governance Melalui Pelayanan Publik. Yogyakarta, UGM Press.

Triwibowo, Ananto \& Rahmani Timorita. 2017. Penerapan Prinsip-Prinsip GCG dalam Pengelolaan Wakaf Tunai pada Badan Wakaf Uang Tunai MUI Yogyakarta. Universitas Islam Indonesia Yogyakarta.

Undang-undang Republik Indonesia No. 41 Tahun 2004 tentang Wakaf.

Yuliafitri, Indri \& Rivaldi, I.A. 2017. Pengaruh Penerapan Prinsip-prinsip Good Governance dan Promosi Terhadap Penerimaan Wakaf Tunai. Jurnal Investasi. Vol. 13, no. 1, 217- 226 


